Original Research

\title{
Self-Efficacy and Health Status in Coronary Artery Disease Patients
}

\author{
Wantiyah Wantiyah, Mochamad Riko Saputra, and Fitrio Deviantony
}

Faculty of Nursing, Universitas Jember, East Java, Indonesia

\begin{abstract}
Introduction: Coronary Artery Disease (CAD) impairs all aspects of the patient's life due to the decrease in physical function and lower quality of life, indicating an overall decreased health status. Self-efficacy as a psychological factor plays an important role in individuals maintaining a healthy lifestyle and improving their health status. The aim of this study was to analyze the correlation between selfefficacy and the health status of coronary artery disease patients.
\end{abstract}

Methods: This study used an observational analytic research design with a crosssectional approach. This study involved 112 respondents who were coronary artery disease patients in RSD Dr. Soebandi Jember obtained through the incidental sampling method. The data was collected using Cardiac Self-Efficacy (CSE) and Seattle Angina Questionnaire (SAQ). The data analysis used the Spearman rank test with a $95 \%$ CI.

Results: The results showed that there was a significant relationship between selfefficacy and health status ( $p=0,001, r=0.307, \alpha=0,05)$. Self-efficacy was in good category $(71,41$ points) while health status was also in the good category $(79,56$ points).

Conclusion: The low positive correlation between the two variables shows that the higher the value of self-efficacy, the higher the value of health status. Good selfefficacy through healthy living behaviors can increase the health status of coronary heart disease patients. It is important for nurses to improve the psychological aspect of the patients including self-efficacy when optimizing their self-care and health status.

\section{ARTICLE HISTORY}

Received: January 21, 2020

Accepted: February 24, 2020

\section{KEYWORDS}

coronary artery disease self-efficacy; health status

\section{CONTACT}

\section{Wantiyah Wantiyah}

$\bowtie$ wantiyah.psik@unej.ac.id

$\square^{\prime}$ Faculty of Nursing, Universitas Jember, East Java, Indonesia

Cite this as: Wantiyah, W., Saputra, M, R., \& Deviantony, F. (2020). Self-Efficacy and Health Status in Coronary Artery Disease Patients. Jurnal Ners, 15(1), 14-18. doi:http://dx.doi.org/10.20473/jn.v14i1.17628

\section{INTRODUCTION}

Coronary artery disease (CAD) is one of the most prevalent killer diseases in the world. The most common manifestations of underlying coronary heart disease are the presence of angina and myocardial infarction. Patients often experience symptoms of distinctive pain in the chest that spreads to the neck, jaw, ears, arms, and wrists, and possibly to the shoulder blades, back or abdomen. In connection with the effects of pain that are felt to be subjective, this can lead to psychological limitations such as anxiety arising from the sudden onset of illness and a fear of sudden death (Beltrame, 2017). Due to the feeling of pain, the physical restrictions, social disability, anxiety and depression, CAD patients are very vulnerable to a decline in health status (De Smedt et al., 2015; Le, Dorstyn, Mpfou, Prior, \& Tully, 2018).
The symptom-based burden of CAD becomes the focus of attention because it is an impact that is felt directly by the patient (Stahle \& Cider, 2018). The impact of the symptoms can cause physical limitations in terms of walking, climbing the stairs and other daily activities (Suputra, 2015). Healthy behavior must still be applied in order to maintain the stability of the health status of patients with heart disease (Nuraeni, 2016). Because CAD threatens the lives of sufferers in an ongoing manner, it needs there to be a good management of health continuously. CAD can be prevented through healthy lifestyle behaviors (Hendiarto, 2014). The psychosocial construct that plays a role in healthy behavior is self-efficacy. It is a strong predictor of the ability to adopt healthy 
lifestyle changes (Bailey, Kashani, Eliasson, \& Vernalis, 2013). Cardiac self-efficacy in cardiac patients is a specific measure of a patient's confidence in his capacity to perform activities that may be affected by the symptoms and complications of cardiovascular disease (Barham, Ibraheem, \& Zyoud, 2019). Self-efficacy makes a difference in how individuals feel, think and act. The level of specific self-efficacy in cardiovascular health is related to important behavioral determinants of cardiovascular health such as a high-fat diet, physical activity, smoking cessation and high blood pressure control through active stress management (Wigger, 2011). In this case, self-efficacy can influence health behavior and chronic disease management in many chronic disease settings (Sarkar, Ali, \& Whooley, 2007). Healthy behavior, as a major factor, can reduce the risk of disease from becoming more severe and increase the success of any treatment and surgery that is to be performed (Nuraeni, 2016)

Research findings in the United States show that on average, CAD patients have less self-efficacy. This low level of self-efficacy is associated with the risk of poor health management (Sarkar, Ali, \& Whooley, 2009). Poor health management behavior is also indicated by poor dietary arrangements and irregular control after returning home following hospitalization (Wantiyah, 2010). CAD patients with lower initial self-efficacy are more likely to be hospitalized for heart failure. In fact, with each standard deviation (22\%), the decrease in the participants' self-efficacy is $40 \%$ more likely to resulting in them being hospitalized with heart failure and they are $30 \%$ more likely to die (Sarkar et al., 2009). In addition, low self-efficacy involves many of the risk factors for existing heart disease. This is indicated by the research involving 71 respondents; $81.6 \%$ of the respondents (as many as 58 ) had low self-efficacy with many of the risk factors (Bailey et al., 2013)

Coronary artery disease is a chronic disease that lasts for the duration of a patient's life that is able to cause fluctuations in their health status from optimal function through to dropping dramatically due to recurrence. This can be life threatening (Wantiyah, 2010). This disease requires complex treatment management including not only medication adherence but also a healthy lifestyle. Self-efficacy is important in the management of CAD because it comes from the individual who feels the impact of the disease. This is improved through the motivation to change into having a good level of health management and decision making in reference to their care (Hendiarto, 2014; Riegel et al., 2017). The ability to manage their lifestyle as a form of good self-efficacy is needed, especially when managing their exposure to risk factors. People tend to ignore this and have unhealthy lifestyles such neglecting to lessen the sodium in their diet and eating high-lipid foods. These both have an impact on the development of cardiovascular disease. This study hypothesis is that
Table 1. Characteristics of the Respondents ( $n=112)$

\begin{tabular}{|c|c|c|}
\hline Characteristics of the Respondents & $\mathbf{n}$ & $\%$ \\
\hline \multicolumn{3}{|l|}{ Gender } \\
\hline Men & 91 & 81.25 \\
\hline Women & 21 & 18.75 \\
\hline \multicolumn{3}{|l|}{ Age } \\
\hline$<45$ years old & 4 & 3.57 \\
\hline $45-54$ years old & 15 & 13.39 \\
\hline $55-64$ years old & 61 & 54.47 \\
\hline $65-74$ years old & 27 & 24.11 \\
\hline$>74$ years old & 5 & 4.46 \\
\hline \multicolumn{3}{|l|}{ Education } \\
\hline No school & 7 & 6.25 \\
\hline Graduated from elementary school & 17 & 15.18 \\
\hline Graduated from middle school & 17 & 15.18 \\
\hline Graduated from high school & 45 & 40.18 \\
\hline College & 26 & 23.21 \\
\hline \multicolumn{3}{|l|}{ Occupational Status } \\
\hline Does not work & 53 & 47.32 \\
\hline Labor & 9 & 8.04 \\
\hline Farmers & 8 & 7.14 \\
\hline General employees & 12 & 10.71 \\
\hline entrepreneur & 17 & 15.18 \\
\hline Civil servants & 11 & 9.82 \\
\hline Indonesian National Army/ & 2 & 1.79 \\
\hline Indonesian Republic Police & & \\
\hline \multicolumn{3}{|l|}{ Income } \\
\hline$<\operatorname{Rp} 2,000,000$ & 49 & 43.75 \\
\hline$\geq \operatorname{Rp} 2,000,000$ & 63 & 56.25 \\
\hline \multicolumn{3}{|l|}{ Marital Status } \\
\hline Single & 0 & 0 \\
\hline Married & 104 & 92.9 \\
\hline Widowed & 8 & 7.1 \\
\hline \multicolumn{3}{|l|}{ Smoking History } \\
\hline Never & 35 & 31.2 \\
\hline Ever & 77 & 68.8 \\
\hline \multicolumn{3}{|l|}{ Disease History } \\
\hline Do not have & 48 & 42.86 \\
\hline Hypertension (High Blood Pressure) & 48 & 42.86 \\
\hline Stroke & 0 & 0 \\
\hline Diabetes Mellitus (Sugar Disease) & 14 & 12.5 \\
\hline Have others & 2 & 1.78 \\
\hline \multicolumn{3}{|l|}{$\begin{array}{l}\text { History of Chest Pain (Angina) in the } \\
\text { past month }\end{array}$} \\
\hline No Chest Pain & 81 & 72.3 \\
\hline There is Chest Pain & 31 & 27.7 \\
\hline
\end{tabular}

self-efficacy has a correlation with perceived health status among patients with CAD.

\section{MATERIALS AND METHODS}

This study used an observational analytical design with a cross-sectional approach. The sample used in this study consisted of CAD patients post-outpatient treatment in the Heart Clinic of RSD Dr. Soebandi Jember. In total, 112 patients with CAD were selected as the research participants according to the criteria established by the researcher. The measurement of the sample size used the application of $\mathrm{G}^{*}$ Power with a power analysis of 0.90 .

The sampling technique used in this research was incidental sampling. This sampling technique determined the sample based on coincidence, where anyone who incidentally meets the researcher and who fits the inclusion and exclusion criteria can be sampled (Nursalam, 2017; Sugiyono, 2016). The data 
Table 2. The Value of Self-Efficacy in CAD Patients in RSD Dr. Soebandi Jember ( $n=112)$

\begin{tabular}{ccc}
\hline Variable & Mean & SD \\
\hline Self-Efficacy & 71.41 & 5.45 \\
\hline
\end{tabular}

Table 3. Health Status Value in CAD Patients in RSD Dr. Soebandi Jember $(n=112)$

\begin{tabular}{lccc}
\hline \multicolumn{1}{c}{ Variable } & Mean & Median & Min-Max \\
\hline $\begin{array}{l}\text { Physical } \\
\text { Limitations }\end{array}$ & 68.44 & 67.78 & $20-100$ \\
$\begin{array}{l}\text { Symptoms } \\
\text { burden }\end{array}$ & 89.94 & 96.67 & $20-100$ \\
$\begin{array}{l}\text { Treatment } \\
\text { Satisfaction }\end{array}$ & 84.41 & 86.25 & $47.50-100$ \\
$\begin{array}{l}\text { Quality of Life } \\
\text { Health Status }\end{array}$ & 79.57 & 83.33 & $33.33-100$ \\
\hline
\end{tabular}

Table 4. The Correlation between Self-Efficacy and Health Status in CAD Patients in RSD Dr. Soebandi Jember $(\mathrm{n}=112)$

\begin{tabular}{lcc}
\hline \multicolumn{1}{c}{ Variable } & p & r \\
\hline $\begin{array}{l}\text { Self-Efficacy } \\
\text { Health Status }\end{array}$ & 0.001 & 0.307 \\
\hline
\end{tabular}

collection process was carried out in January 2020 in the Heart Outpatient ward of RSD Dr. Soebandi Jember. The process of taking the data used an instrument in the form of a demographic characteristic questionnaire. The self-efficacy measurement was done using the Cardiac SelfEfficacy (CSE) questionnaire by Sullivan translated and adapted to Bahasa Indonesian. This was found to be valid and reliable with a Cronbach's Alpha reliability of 0.77 (Wantiyah, 2010). The health status measurement was done using the Indonesian version of Seattle Angina Questionnaire (SAQ). The validity and reliability values in general for the SAQ questionnaire were in the range of 0.477-0.577 and the Cronbach's Alpha value was 0.866 (Nurhalimah, 2016). The data analyses used a Spearman rank test with a 95\% CI by using SPSS 26 to determine the relationship between the two variables, namely selfefficacy and health status in patients with CAD.

This study was declared to have passed the ethical test conducted by the Health Research Commission of the Faculty of Dentistry at the University of Jember with Ethics committee approval number No. 706/UN25.8/KEPK/DL/2019. All of the respondents in this study were given informed consent. The study respondents had the right to refuse to participate without penalty if they wished to do so.

\section{RESULTS}

The respondent's demographic characteristics including age, gender, education, occupational status, income, marital status, history of disease and history of heart attack in the past month have collectively been displayed in Table 1. Based on Table 1, most of the respondents $(81.25 \%)$ were men. The respondents were dominated by those in the age range of 55-64 years, totaling 61 respondents
(54.47\%). The most common educational history of the respondents was having graduated Senior high school, totaling 45 respondents (40.18\%). Most respondents did not work, totaling 53 respondents $(47.32 \%)$. In relation to this, 63 respondents (56.25\%) earn more than Rp. 2,000,000.00. Almost all of the respondents are married (92.9\%). The respondents' smoking history shows that 77 respondents $(68.8 \%)$ have a history of smoking and that 48 respondents (42.86\%) have hypertension. Chest pain experienced by the respondents during the past month showed that as many as 81 respondents $(72.3 \%)$ did not complain of a heart attack in the past month.

In Table 2, the self-efficacy measurement by CSE shows an average value of 71.41 (SD: 5.45). In Table 3 , the health status measurement by SAQ shows an average value of 79.56, which indicates that the average health status of CAD patients is included in the good category because the criteria value $\geq 72.03$ is the natural cut-off point. The median value is 80.39 with a minimum value of 49.06 and a maximum value of 95. It is known that the indicator with a high average score has a symptom load of 89.9 with a minimum value of 20 and a maximum value of 100 . The indicator with the lowest average value was physical limitations, equal to 68.4 with a minimum value of 20 and a maximum value of 100 .

Table 4 shows that there is a correlation between self-efficacy and health status in CAD patients. The Spearman rank test correlation coefficient value of 0.307 shows that the correlation category of the relationship between the two variables is low. The direction of the relationship shows there to be a positive value which means that the higher or better the self-efficacy, the higher or better the health status of the CAD patients.

\section{DISCUSSION}

This study found that there is a relationship between self-efficacy in reference to the ability to manage the changeable risk factors with health status. The study findings show that good self-efficacy has a positive effect on the perception of the health status of CAD patients. This can impact their condition and any improvements. The improvement is indicated by the low complaint of angina recurrence and other symptoms of a heart attack. The level of specific selfefficacy on cardiovascular health is related to the important behavioral determinants of cardiovascular health such as a high-fat diet, physical activity, smoking cessation and high blood pressure control through active stress management (Wigger, 2011).

The statistical analysis results show that there is a relationship between the self-efficacy variable with the variable of the health status of CAD patients. The correlation category shows that the relationship between the two variables has a low correlation. The relationship between the two variables has a positive relationship. The nature of the relationship shows that good self-efficacy associated with health 
management will have an impact on the better health status of the CAD patients. This is supported by the research by Ahn, Song, \& Choi, (2016) which shows that there is a relationship between the variables, where self-efficacy, self-health behavior and the risk factors that can be changed have an important role in improving the quality of life of CAD patients through the better and effective management of cardiovascular risk factors. Research by Sarkar, Ali, \& Whooley (2007) shows that among patients with CAD, low cardiac self-efficacy is associated with poor health status, independent of CAD severity and depressive symptoms. The lack of self-efficacy in cardiac patients is associated with good selfacceptance. Individuals who have good selfacceptance can mean that they can accept both their weaknesses and strengths with realistic expectations. They can respect themselves. Individuals claim to be able to accept their conditions in various aspects positively and be able to live life well (Puspita, 2018). According to Bandura (1994), good self-efficacy is able to bring in adaptive behaviors, especially in the prevention of a health problem. Preventive efforts that are intended are efforts to reduce or control the risk factors that are detrimental to health. These efforts include being physically active, maintaining blood pressure, and developing various ways to manage stress (Buchanan, 2016).

The low correlation of the two variables as indicated by the findings of the study in some patients showed good self-efficacy but a poor level of health status. These results are irrelevant because the patient's self-efficacy began to be high after they were diagnosed with CAD, especially in new patients. It is known that CAD is a disease that is caused by a long period of exposure to the risk factors. A drastic change in self-efficacy when the patient changes his behavior in terms of health management and risk exposure does not show significant results in terms of improving their health status immediately.

\section{CONCLUSION}

Based on the research findings and discussion, it can be concluded that there is a relationship between selfefficacy and health status in patients with coronary heart disease at a low correlation level. The results showed that the better the self-efficacy of the patients with coronary heart disease, the better their health status.

Prospective studies can explore, using qualitative methods, matters related to self-efficacy and health status including the patient perceptions related to the symptoms and limitations in terms of CAD given how the opinions, ideas and assumptions will be broader than just the symptoms themselves.

\section{REFERENCES}

Ahn, S., Song, R., \& Choi, S. W. (2016). Effects of Selfcare Health Behaviors on Quality of Life Mediated by Cardiovascular Risk Factors Among Individuals with Coronary Artery Disease: A Structural
Equation Modeling Approach. Asian Nursing Research, 10(2), 158-163. https://doi.org/10.1016/j.anr.2016.03.004

American Thoracic Society. (2007). Key Concept: Health Status, and Health Perceptions. Retrieved October 19, 2019, from https://qol.thoracic.org/sections/keyconcepts/health-status-health-perceptions.html

Bailey, K., Kashani, M., Eliasson, A., \& Vernalis, M. (2013). Low Self-Efficacy Correlates with Increased Cardiovascular Disease Risk. Circulation Cardiovascular Quality and Outcomes, 6(a626).

Bandura, A. (1994). Self-Efficacy. In V. S. Ramachaudran (Ed.), Encyclopedia of human behavior. New York: Academic Press

Barham, A., Ibraheem, R., \& Zyoud, S. H. (2019). Cardiac self-efficacy and quality of life in patients with coronary heart disease: A cross-sectional study from Palestine. BMC Cardiovascular Disorders, 19(1), 1-12. https://doi.org/10.1186/s12872-019-01281-7

Beltrame, J. F. (2017). Impact of Chronic Stable Angina on Health Status. Medicographia, 39(1), 11-16.

Buchanan, J. (2016). Albert Bandura: Self-Efficacy for Agentic Positive Psychology. Retrieved October 26, 2019, from Positive Psychology website: https://positivepsychology.com/bandura-selfefficacy/

De Smedt, D., Clays, E., Annemans, L., Pardaens, S., Kotseva, K., \& De Bacquer, D. (2015). SelfReported Health Status in Coronary Heart Disease Patients: A Comparison with The General Population. European Journal of Cardiovascular Nursing, 14(2), 117-125. https://doi.org/10.1177/1474515113519930

Hendiarto, Y. (2014). Hubungan Antara Self-Efficacy dengan Perilaku Sehat pada Penderita Jantung Koroner. Jurnal Psikologi Klinis Dan Kesehatan Mental, 03(02), 85-89.

Hidayat, A. (2017). Pilihan Uji Normalitas Berdasarkan Software-Jumlah Sample. Retrieved November 11, 2019, from http://statistikian.com/ Le, J., Dorstyn, D. S., Mpfou, E., Prior, E., \& Tully, P. J. (2018). Health-Related Quality of Life in Coronary Heart Disease: A Systematic Review and Metaanalysis Mapped Against the International Classification of Functioning, Disability, and Health. Quality of Life Research, 27(10), 24912503. https://doi.org/10.1007/s11136-0181885-5

Nuraeni, A. (2016). Faktor yang Memengaruhi Kualitas Hidup Pasien dengan Penyakit Jantung Koroner. Jurnal Keperawatan Padjadjaran, 4(2), 107-116. https://doi.org/10.24198/jkp.v4n2.1

Nurhalimah, A. (2016). Hubungan Kesejahteraan Spiritual Dengan Kualitas Hidup Pasien Sindrom Koroner Akut di Poliklinik Jantung RSUP Dr. Hasan Sadikin Bandung. Skripsi, Sumedang, Fakultas Keperawatan Universitas Padjadjaran.

Nursalam. (2017). Metodologi Penelitian Ilmu Keperawatan Pendekatan Praktis (4th ed.). Jakarta: Salemba Medika. 
Polit, D. F., \& Beck, C. T. (2010). Essentials of Nursing Research Seventh Edition Appraising Evidence for Nursing Practice (7th ed.). https://doi.org/10.1017/CBO9781107415324.0 04

Puspita, R. D. (2018). Hubungan antara Self Efficacy dengan Penerimaan Diri pada Pasien Penyakit Jantung. Skripsi, Sleman, Program Studi Psikologi Universitas Islam Indonesia.

Riegel, B., Moser, D. K., Buck, H. G., Dickson, V. V., Dunbar, S. B., Lee, C. S., ... Webber, D. E. (2017). Self-Care for the Prevention and Management of Cardiovascular Disease and Stroke. Journal of the American Heart Association, 6(9).

Rumsfeld, J. S., Alexander, K. P., Goff, D. C., Graham, M. M., Ho, P. M., Masoudi, F. A., ... Zerwic, J. J. (2013). Cardiovascular Health: The Importance of Measuring Patient-Reported Health Status A Scientific Statement From the American Heart Association. Circulation, 127, 2233-2249. https://doi.org/10.1161/CIR.0b013e3182949a2 e

Sarkar, U., Ali, S., \& Whooley, M. A. (2007). Selfefficacy and Health Status in Patients with Coronary Heart Disease: Findings from The Heart and Soul Study. Psychosomatic Medicine, 69(4), 306-312. https://doi.org/10.1097/PSY.0b013e3180514d5 7

Sarkar, U., Ali, S., \& Whooley, M. A. (2009). SelfEfficacy as a Marker of Cardiac Function and
Predictor of Heart Failure Hospitalization and Mortality in Patients With Stable Coronary Heart Disease : Findings From the Heart and Soul Study. Health Psychology, 28(2), 166-173. https://doi.org/10.1037/a0013146

Stahle, A., \& Cider, A. (2018). Physical Activity in The Prevention of Treatment and Disease. In Coronary Artery Disease (pp. 283-299). Sweden: Swedish Research Council.

Sugiyono. (2016). Metode Penelitian Kuantitatif, Kualitatif dan R\&D. Bandung: Alfabeta.

Suputra, P. A. (2015). Latihan Fisik pada Penderita Koroner. Proceedings Seminar Nasional FMIPA UNDIKSHA $V$, 342-346.

Wagner, J., Knaier, R., Infanger, D., Arbeev, K., Briel, M., Dieterle, T., ... Schmidt-Trucksäss, A. (2019). Functional aging in health and heart failure: The COmPLETE Study. BMC Cardiovascular Disorders, 19(1), 1-17. https://doi.org/10.1186/s12872019-1164-6

Wantiyah. (2010). Analisis Faktor-Faktor yang Mempengaruhi Efikasi Diri Pasien Penyakit Jantung Koroner dalam Konteks Asuhan Keperawatan di RSD dr. Soebandi Jember. Thesis, Depok, Fakultas Ilmu Keperawatan Universitas Indonesia.

Wigger, E. (2011). Self-Efficacy and Heart Disease. In Psychological Risk Factor. Retrieved October 18, 2019, from https://unhealthywork.org/psychological-riskfactors/self-efficacy-and-heart-disease/ 